\title{
Buku Pedoman Permainan Tradisional untuk Menumbuhkan Karakter Empati Anak Usia 9-12 Tahun
}

\author{
Yasinta Elva Fajarwati ${ }^{*}$, Gregorius Ari Nugrahanta ${ }^{2}$ (ID \\ 1,2 Jurusan Ilmu Pendidikan, Universitas Sanata Dharma, Yogyakarta, Indonesia \\ *Corresponding author: yasintaelva17@gmail.com
}

\begin{abstract}
Abstrak
Masalah pendidikan di Indonesia sangatlah kompleks karena di semua aspeknya terdapat persoalan yang perlu diselesaikan. Degradasi moral telah merajalela dalam dunia pendidikan sehingga menjadi dampak buruk dalam dunia pendidikan. Penelitian ini bertujuan untuk menciptakan buku pedoman permainan tradisional untuk menumbuhkan karakter empati anak usia 9-12 tahun. Jenis penelitian ini adalah penelitian pengembangan atau Research and Development (R\&D). Penelitian ini melibatkan melibatkan 7 guru Sekolah Dasar yang sudah tersertifikasi dari berbagai daerah untuk melakukan analisis kebutuhan, 8 validator untuk expert judgement, dan6 anak untuk uji coba buku pedoman secara terbatas. Teknik yang digunakan untuk pengumpulan data adalah teknik nontes dan tes. Teknik nontes ditujukan kepada guru untuk instrumen analisis kebutuhan dengan kuesioner terbuka dan tertutup. Teknik analisis data menggunakan analisis kuantitatif dengan program komputer IBM SPSS Statistics version 22 for Windows. Hasil penelitian menunjukkan bahwa kualitas buku pedoman permainan tradisional memiliki rerata skor sebesar 3,93 (skala 1-4), dengan rekomendasi "sangat baik". Penerapan buku permainan tradisional berpengaruh terhadap karakter empati anak usia 9-12 tahun. Hasil uji signifikansi $\mathrm{t}(5)=12.969, \mathrm{p}=0,000(\mathrm{p}<0,05)$. Besar pengaruh sebesar $r=0,985$ yang masuk kategori "efek besar" setara dengan pengaruh $97,10 \%$, artinya penerapan buku pedoman permainan tradisional ini dapat menjelaskan $97,10 \%$ perubahan varian yang terjadi pada karakter empati anak. Tingkat efektivitas ditunjukkan dengan N-gain score sebesar $92.012 \%$ yang masuk dalam kategori "Tinggi”. Maka, buku pedoman permainan tradisional layak dan efektif digunakan dalam menumbuhkan karakter empati anak usia 9-12 tahun.
\end{abstract}

Kata kunci: Permainan tradisional, karakter empati, buku.

\section{Abstract}

The problem of education in Indonesia is very complex because in all its aspects there are problems that need to be solved. Moral degradation has been rampant in the world of education so that it becomes a bad impact in the world of education. This study aims to create a traditional game guidebook to cultivate the empathetic character of children aged 9-12 years. This type of research is research and development $(R \& D)$. This study involved 7 certified elementary school teachers from various regions to conduct a needs analysis, 8 validators for expert judgment, and 6 children for a limited trial of manuals. The technique used for data collection is non-test and test techniques. The non-test technique is addressed to teachers for needs analysis instruments with open and closed questionnaires. The data analysis technique used quantitative analysis with the computer program IBM SPSS Statistics version 22 for Windows. The results showed that the quality of the traditional game manual had an average score of 3.93 (scale 1-4), with a recommendation of "very good". The application of traditional game books has an effect on the empathetic character of children aged 9-12 years. The results of the significance test $t(5)=12,969$, $p=0.000(p<0.05)$. The magnitude of the effect of $r=0.985$ which is included in the "big effect" category is equivalent to the effect of $97.10 \%$, meaning that the application of this traditional game manual can explain $97.10 \%$ of the variance changes that occur in children's empathetic characters. The level of effectiveness is indicated by the N-gain score of $92.012 \%$ which is included in the "High" category. So, traditional game manuals are feasible and effective to use in developing empathetic characters for children aged 9-12 years.

Keywords: Traditional games, emphaty character, manual

\section{INTRODUCTION}

Pendidikan karakter menjadi modal dasar dan pedoman yang kuat untuk pengembangan setiap individu anak (Christopher et al., 2019; Nurdin et al., 2021). Pendidikan karakter adalah proses anak diberikan suatu tuntutan agar mempunyai karakter dalam aspek hati, pikir, raga, serta karsa dan karya (Nugrahani, 2017; Prasanti \& Fitrianti, 2018; Wisnu Budi Wijaya, 2019). Pendidikan karakter merupakan usaha agar anak dapat berkontribusi secara positif dengan mampu mengambil keputusan yang bijak dan menerapkannya dalam kehidupan sehari-hari (Hidayah, 2015; Nurohmah \& Dewi, 2021). Pembelajaran yang efektif dapat dijadikan sebagai

$\begin{array}{ll}\text { History: } & \\ \text { Received } & \text { : October 10, } 2021 \\ \text { Revised } & \text { : October 12, } 2021 \\ \text { Accepted } & : \text { November 19, 2021 } \\ \text { Published } & \text { : November 25, 2021 }\end{array}$


penyelesaian dari tantangan pembelajaran abad 21 (Andrian \& Rusman, 2019; Haryanti \& Saputra, 2019). Abad 21 ditandai dengan perkembangan pesat ilmu pengetahuan dan teknologi (IPTEK). Hal ini menuntut siswa tidak hanya memiliki keterampilan yang kuat di berbagai bidang, tetapi mereka juga harus mahir dalam keterampilan seperti berpikir kritis, pemecahan masalah, kolaborasi, dan rasa ingin tahu (Komara, 2018; Redhana, 2019). Pembelajaran yang efektif dapat membentuk moralitas siswa yang terbentuk dengan perbuatan berulang-ulang dan akan menjadi kebiasaan. Pembelajaran yang efektif adalah pembelajaran yang membuat siswa lebih mudah untuk mempelajari sesuatu yang bermanfaat seperti fakta, keterampilan, nilai, konsep, atau suatu hasil belajar yang diinginkan (Estiani et al., 2015; Ramadhani \& Fauziah, 2020).

Namun kenyataannya, masalah pendidikan di Indonesia sangatlah kompleks karena di semua aspeknya terdapat persoalan yang perlu diselesaikan. Degradasi moral telah merajalela dalam dunia pendidikan sehingga menjadi dampak buruk dalam dunia pendidikan (Priska, 2020; Priyanasari \& Susanti, 2021). Hal ini bisa dilihat dari maraknya perkelahian antar pelajar, banyaknya kasus narkoba yang menjerat siswa. Siswa yang menunjukkan sikap kurang hormat kepada orang dewasa, kasus menyontek yang sudah menjadi kebiasaan (Nurohmah \& Dewi, 2021; Sugiarto et al., 2019). Persoalan budaya dan karakter bangsa saat ini menjadi sorotan tajam masyarakat. Berdasarkan data UNICEF sebanyak 21\% kasus perundungan atau bullying yang terjadi pada anak cukup tinggi di Daerah Istimewa Yogyakarta. Semakin maraknya kasus tersebut, menunjukkan pentingnya karakter empati dikembangkan sejak usia dini. Empati merupakan sebuah emosi moral yang dapat membantu anak memahami perasaan orang lain dengan baik. Empati merupakan kemampuan dalam memahami perasaan orang lain (Mashar, 2015; Rakimahwati, 2012). Karakter empati ditunjukkan dengan indikator kepekaan sosial, peduli, memahami bahasa tubuh, memahami ekspresi, memahami kesedihan, memahami situasi, sadar kesalahan, menentang ketidakadilan, memahami pendapat lain, mengungkapkan secara lisan (Juanda, 2019; Mashar, 2015).

Salah satu upaya untuk menumbuhkan karakter empati, yaitu dengan permainan tradisional. Permainan tradisional merupakan suatu aktivitas permainan yang tumbuh dan berkembang di daerah tertentu, yang terkandung nilai-nilai budaya dan tata nilai kehidupan masyarakat dan diajarkan secara turun-temurun (Kurniati, 2016). Dalam merancang model pembelajaran pendidikan karakter empati, diperlukan upaya yang relevan dan pendekatan multidimensi (Pitaloka et al., 2021; Putry, 2019). Untuk mendasari konsep pembelajaran yang efektif, digunakan beberapa pendekatan sekaligus, yaitu pendekatan Brain Based Learning, kontruktivisme, pembelajaran abad 21, dan multikultur. Pembelajaran yang efektif memenuhi sepuluh indikator, yaitu kaya variasi, kaya stimulasi, menyenangkan, operasional konkret, berpikir kritis, kreativitas, komunikasi, kolaborasi, multikultur, dan empati (Andrian \& Rusman, 2019; Groth et al., 2018). Pembelajaran yang efektif tentunya memaksimalkan fungsi otak. Brain Based Learning (BBL) merupakan pembelajaran yang disesuaikan dengan cara otak yang dirancang secara natural untuk belajar, lebih mengutamakan pada kesenangan siswa terhadap belajar sehingga dengan mudah siswa menerima materi yang sedang dipelajari (Sugiarti et al., 2021; Yustitia \& Juniarso, 2018). Strategi utama yang dapat dikembangkan dalam implementasi Brain Based Learning adalah kaya variasi, kaya stimulasi, dan menyenangkan (Greipl et al., 2021; Sugiarti et al., 2021). Pembelajaran berbasis otak pada prinsipnya akan lebih menyenangkan pada kegiatan dalam interaksi sosial atau kelompok.

Temuan penelitian sebelumnya menyatakan permainan tradisional dapat meningkatkan kemampuan gerak dasar siswa sekolah dasar kelas bawah (Kusumawati, 2017). Permainan tradisional juga dapat meningkatkan keterampilan sosial pada mata pelajaran IPS (Handayani, 2017). Model pembelajaran permainan tradisional pun efektif sebagai sarana untuk menstimulasi aspek perkembangan anak (Munawaroh, 2018). Bahan ajar tematik-integratif efektif dapat meningkatkan karakter tanggung jawab dan disiplin peserta didik (Baka et al., 
2018; Laksana et al., 2016). Selain itu, aktualisasi pendidikan karakter berbasis kultur sekolah dalam pembelajaran IPS dapat meningkatkan karakter (Rosyad \& Zuchdi, 2018) (Rosyad \& Zuchdi, 2018). Beberapa penelitian tersebut lebih banyak mengkaji tentang pendidikan karakter secara keseluruhan dan tidak spesifik. Selain itu juga penelitian-penelitian tersebut hanya menggunakan satu pendekatan saja. Kebaruan dari penelitian ini dibandingkan dengan penelitian-penelitian terdahulu bisa diringkas dalam tiga unsur yaitu multidimensi, konsentris, dan gradualitas. Pertama, jika kebanyakan penelitian lebih berfokus pada satu dimensi, metode, atau pendekatan untuk mengembangkan produk, penelitian ini menggunakan pendekatan yang multidimensi, yaitu pendekatan berdasarkan BBL, konstruktivisme menurut Piaget dan Vygotsky, pembelajaran abad 21, dan multikultur. Kedua, penelitian ini menggunakan model konsentris yang mengembangkan berbagai kegiatan untuk mencapai satu tujuan. Ketiga, instrumen pengambilan data mencoba memetakan karakter dalam proses gradual yang tampak dari pilihan jawaban yang tersedia. Tujuan dari penelitian ini untuk mengembangkan buku pedoman permainan tradisional untuk menumbuhkan karakter empati anak usia 9-12 tahun.

\section{MATERIALS AND METHODS}

Penelitian ini menggunakan jenis penelitian Research and Development (R\&D) tipe ADDIE (Analyze, Design, Develop, Implement, dan Evaluate). Penelitian ini menggunakan dua objek penelitian, yaitu buku pedoman permainan tradisional sebagai variabel independen dan karakter empati sebagai variabel dependen. Tahap analyze dilakukan untuk menemukan kesenjangan antara model pembelajaran dan metode pembelajaran yang seharusnya diimplementasikan dan model pembelajaran yang senyatanya digunakan. Tahap ini dilakukan dengan memberikan instrumen analisis kebutuhan kuesioner tertutup dan kuesioner terbuka. Kuesioner-kuesioner tersebut diberikan kepada tujuh guru yang sudah tersertifikasi (PNS) yang berada di wilayah Gunungkidul, Sleman, Bantul, Karanganyar, Wonogiri, Sukoharjo, dan Kepulauan Meranti. Tahap design dilakukan untuk pembuatan kerangka buku pedoman permainan tradisional dengan mengembangkan sepuluh indikator pembelajaran yang efektif. Buku pedoman memuat lima permainan tradisional dari berbagai daerah, yaitu Nglarak Blarak dari Daerah Istimewa Yogyakarta, Grapyak dari Jawa Tengah, Rerebonan dari Jawa Barat, Landar-Lundur dari Jakarta Utara, dan Lompat Bambu dari Flores.

Tahap develop ini dikembangkan prototype produk sebagai solusi terhadap permasalahan dengan mengembangkan sumber-sumber belajar, memvalidasi dan merevisi draf rancangan, dan melakukan validasi melalui expert judgement guna mendapatkan feedback untuk memperbaiki prototype produk sebelum diimplementasikan secara konkret. Tahap implement ini, buku pedoman permainan tradisional diujicobakan dengan enam anak sebagai subjek yang terdiri dari tiga anak perempuan dan tiga anak laki-laki dengan usia 9-12 tahun.. Uji coba terbatas dilakukan di Jalan Manthous km 1, RT 45, Dusun Glidag, Desa Logandeng, Kecamatan Playen, Kabupaten Gunungkidul, Daerah Istimewa Yogyakarta. Tahap evaluate dilakukan untuk mengukur seberapa baik produk yang dikembangkan dapat membantu anak dalam mencapai sasaran pembelajaran. Berikut adalah desain penelitian langkah-langkah ADDIE pada Gambar 1.

Teknik yang digunakan untuk pengumpulan data adalah teknik nontes dan tes. Teknik nontes ditujukan kepada guru untuk instrumen analisis kebutuhan dengan kuesioner terbuka dan tertutup. Kuesioner ini digunakan ntuk instrumen analisis kebutuhan. Teknik analisis data menggunakan program komputer IBM SPSS Statistics version 22 for Windows dengan tingkat kepercayaan $95 \%$ dan dengan uji dua ekor (2-tailed). Teknik tes diberikan kepada anak usia 912 tahun berupa pilihan ganda yang disesuaikan dengan sepuluh indicator karakter empati digunakan pada tahap Evaluate sebagai evaluasi formatif dan evaluasi sumatif termasuk yang digunakan dalam pretest dan posttest. Evaluasi sumatif dilakukan di akhir proses pembelajaran 
yang biasanya dilakukan pada 3 level yaitu persepsi, pembelajaran, dan performansi. Hasil analisis diinterpretasikan dengan skala konversi data kuantitatif ke kualitatif dapat dilihat pada Tabel 1.

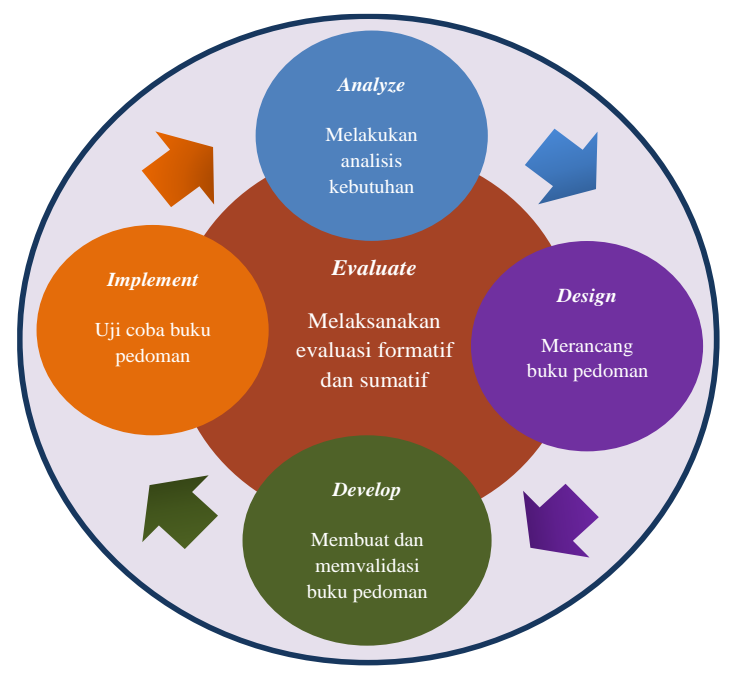

Gambar 1. Model ADDIE

Tabel 1. Konversi Data Validasi Kuantitatif ke Kualitatif

\begin{tabular}{clll}
\hline No. & \multicolumn{1}{c}{ Rentang Skor } & \multicolumn{1}{c}{ Kategori } & \multicolumn{1}{c}{ Rekomendasi } \\
\hline 1 & $3,26-4,00$ & Sangat Baik & Tidak perlu revisi \\
2 & $2,51-3,25$ & Baik & Perlu revisi kecil \\
3 & $1,76-2,50$ & Kurang Baik & Perlu revisi besar \\
4 & $1,00-1,75$ & Sangat Kurang Baik & Perlu dirombak total \\
\hline
\end{tabular}

\section{RESULTS AND DISCUSSION}

\section{Results}

Hasil penelitian sesuai dengan tahap-tahap pengembangan model ADDIE yang terdiri dari analyze, design, develop, implement, dan evaluate. Tahap analyze dilakukan dengan memberikan instrumen analisis kebutuhan kepada tujuh guru yang sudah tersertifikasi yang berada di wilayah Gunungkidul, Sleman, Bantul, Karanganyar, Wonogiri, Sukoharjo, dan Kepulauan Meranti. Rerata keseluruhan skor analisis kebutuhan sebesar 1,55 (skala 1-4) yang termasuk kategori "Sangat kurang baik". Hal itu karena guru kurang maksimal dalam menggunakan model pembelajaran yang bervariasi untuk pendidikan karakter empati. Belum diterapkan pembelajaran atau program khusus untuk menumbuhkan karakter empati bagi anak SD tempat responden mengajar. Hasil tersebut menunjukkan bahwa para responden belum menerapkan pembelajaran atau suatu program yang efektif untuk menumbuhkan karakter empati anak. Hasil kuesioner tertutup berimbang dengan hasil kuesioner terbuka yang menyatakan bahwa upaya pengembangan karakter empati di sekolah tempat responden mengajar masih kurang maksimal, belum berjalan efektif, dan memerlukan inovasi baru. Dengan demikian, terdapat dasar yang kuat untuk menawarkan solusi dalam penelitian ini berupa buku pedoman permainan tradisional untuk menumbuhkan karakter empati pada anak. Tahap design, membuat kerangka produk yaitu buku pedoman permainan tradisional. Peneliti mulai merancang dengan menulis dari bagian awal terdapat cover buku, kata pengantar, dan daftar isi. Bagian tengah buku berisikan teori-teori pembelajaran, menyusun pengembangan permainan tradisional dengan langkah-langkah implementasinya, dilengkapi dengan gambar sistematika, gambar langkah-langkah setiap permainan, soal-soal formatif, dan lagu-lagu yang 
berasal dari berbagai daerah. Bagian akhir dari buku pedoman permainan tradisional dituliskan daftar referensi, soal-soal sumatif, kunci jawaban, glosarium, indeks, dan biodata penulis.

Tahap develop, melakukan validasi produk melalui expert judgement, yang diberikan kepada tiga guru SD yang sudah tersertifikasi, tiga dosen diantaranya yang berlatar belakang psikolog, bahasa, dan seni. Selain itu juga diberikan kepada dua budayawan. Validasi permukaan terdiri dari uji kriteria buku pedoman dan karakteristik buku pedoman. Validasi uji kriteria buku pedoman menunjukkan bahwa indikator cover buku, bagian awal buku, bagian isi buku, dan bagian akhir buku menunjukkan rerata paling tinggi, dengan skor rerata 4,00. Validator 1 yaitu dosen psikologi dengan rerata 3,75; validator 2 yaitu dosen seni dengan rerata 3,94; validator 3 yaitu dosen bahasa dengan rerata 3,94; validator 4, 5, dan 6 yaitu guru SD kelas atas yang sudah tersertifikasi dengan rerata 4,00 dan 3,95. Validator 7 dan 8 yaitu ahli budaya dengan rerata 4,00 dan 3,95. Rerata tertinggi terdapat pada indikator bagian isi buku dan bagian akhir buku dengan skor rerata 4,00. Rerata terendah terdapat pada indikator bagian awal buku, dengan skor rerata 3,89. Rerata keseluruhan hasil validasi uji kriteria buku pedoman diperoleh skor 3,94, yang masuk kategori "sangat baik" dengan rekomendasi "tidak perlu revisi".

Validasi berikutnya yaitu uji karakteristik buku pedoman yang disusun dengan lima indikator yaitu self-instructional, self-contained, stand alone, adaptif, dan user friendly. Uji karakteristik buku pedoman dilakukan dengan tujuan untuk memastikan sejauh mana karakteristik buku pedoman sudah terpenuhi. Instrumen menggunakan skala Likert 1-4 dengan keterangan 4) sangat setuju, 3) setuju, 2) kurang setuju, dan 1) tidak setuju. Hasil validasi uji karakteristik buku pedoman melalui expert judgement menggunakan skala 1-4. Berdasarkan hasil uji validitas karakteristik buku pedoman, indikator user friendly dan indikator selfinstructional memiliki rerata tertinggi dengan skor 4,00. Keseluruhan rerata hasil validasi uji karakteristik buku pedoman diperoleh skor 3,91. Dari tabel konversi data kuantitatif ke kualitatif dan rekomendasi, skor 3,91 masuk kategori "sangat baik" dengan rekomendasi "tidak perlu revisi". Validasi selanjutnya adalah validasi isi. Tujuan validasi isi adalah mengetahui sejauh mana buku pedoman sudah memenuhi indikator-indikator pembelajaran yang efektif sesuai teori-teori pendidikan yang digunakan dalam penelitian ini. Berdasarkan validasi yang sudah dilakukan, maka diperoleh hasil validasi produk dari para validator diperoleh rerata skor indikator rerata paling tinggi dengan skor rerata 4,00 yaitu indikator kaya variasi, kaya stimulasi, menyenangkan, berpikir kritis, komunikasi, dan kolaborasi. Rerata paling rendah terdapat pada indikator operasional konkret dan indikator kreativitas, dengan skor rerata 3,88. Keseluruhan rerata hasil validasi produk diperoleh skor 3,94 masuk dalam kategori "sangat baik" dengan rekomendasi "tidak perlu revisi". Rerata dari keseluruhan hasil uji validasi yaitu uji kriteria buku pedoman, karakteristik buku pedoman, dan validitas isi diperoleh 3,94. Skor tersebut diinterpretasikan dengan skala konversi data kuantitatif ke kualitatif dengan kualifikasi "sangat baik" dan rekomendasi "tidak perlu revisi". Dengan rekomendasi tersebut, maka terlihat jelas kualitas dari buku pedoman permainan tradisional yang dikembangkan melalui validasi permukaan yang mencakup uji kriteria buku pedoman dan uji karakteristik buku pedoman memiliki kualifikasi "Sangat baik". Isi dari buku pedoman permainan tradisional ini sudah mencakup indikator pembelajaran yang efektif dan sesuai dengan pendekatan-pendekatan yang digunakan dalam penelitian ini, dapat dilihat dari skor keseluruhan yang didapat. Penelitian telah melakukan uji coba buku pedoman permainan tradisional secara terbatas terhadap enam anak usia 9-12 tahun. Pada awal implementasi melakukan pretest dan posttest yang mewakili sepuluh indikator empati untuk masing-masing permainan. Hasil uji coba buku pedoman permainan tradisional terjadi peningkatan rerata pretest dan posttest yang digambarkan pada Gambar 2 . 


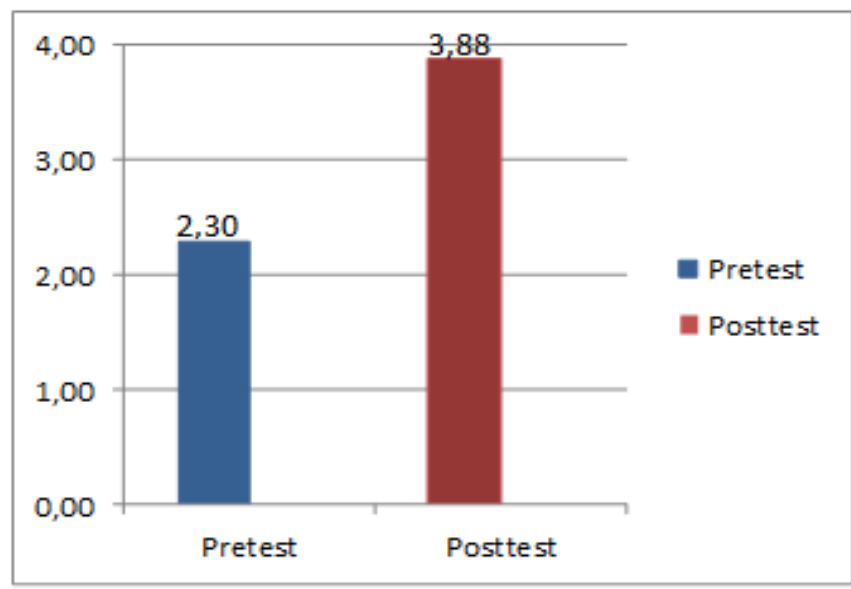

Gambar 2. Kenaikan Rerata Pretest ke Posttest

Hasil menunjukkan bahwa terdapat peningkatan dari hasil rerata skor pretest 2,30 (skala 1-4) dengan hasil rerata skor posttest 3,88 (skala 1-4). Berdasarkan data hasil pretest dan posttest, persentase rerata skor peningkatan sebesar $65,22 \%$. Untuk mengetahui peningkatan tersebut signifikan atau tidak, akan dilakukan uji statistik. Oleh karena itu sebelum dilakukan analisis statistik, perlu diperiksa asumsi-asumsi datanya dengan uji normalitas data. Berdasarkan hasil analisis menggunakan Shapiro-Wilk test, menunjukkan distribusi data yang normal pada Pretest $W(6)=0.950$ dan $p=0.737(p>0.05)$ dan Posttest $W(6)=0.074$ dan $p=$ $0.065(p>0.05)$. Kedua nilai tidak signifikan. $\mathrm{H}_{0}$ tidak berhasil ditolak. Artinya, kedua data terdistribusi secara normal. Dengan demikian syarat normalitas distribusi data terpenuhi. Oleh karena itu, analisis selanjutnya menggunakan statistik parametrik, dengan hal ini paired samples $t$-test. Hipotesis statistik $H_{\text {null }}$ yang digunakan dalam penelitian ini adalah tidak ada perbedaan yang signifikan antara rerata skor pretest dan posttest. Kriteria yang digunakan untuk menolak $H_{\text {null }}$ adalah jika nilai $p<0,05$. Hasil uji signifikansi paired samples $t$-test menunjukkan skor rerata posttest $(M=3,8833, S E=0,05426)$ lebih tinggi dari skor pretest $(M$ $=2,4333, \mathrm{SE}=0,09916)$ dan perbedaan skor tersebut signifikan dengan nilai $t(5)=12.969, p$ $=0,000(p<0,05)$. Dengan demikian, $\mathrm{H}_{0}$ ditolak. Artinya, implementasi buku pedoman permainan tradisional berpengaruh terhadap karakter empati anak usia 9-12 tahun. Setelah mengetahui suatu pengaruh itu signifikan belum memberikan gambaran seberapa besar pengaruh tersebut. Untuk itu perlu dilakukan uji besar pengaruh perlakuan. Rumus untuk mengetahui besar pengaruh (effect size) menggunakan model koefisien korelasi Pearson. Hasil koefisien korelasi $r$ dalam penelitian ini sebesar 0,98 yang masuk kategori efek besar dan setara dengan pengaruh $97,10 \%$. Kriteria untuk menentukan besarnya pengaruh (effect size) pada Tabel 3. Hasil koefisien korelasi $r$ dalam penelitian ini sebesar 0,98 yang masuk kategori efek besar dan setara dengan pengaruh 97,10\%, termasuk dalam kategori "Efek besar". Artinya, implementasi buku pedoman permainan tradisional memiliki pengaruh yang besar terhadap perubahan karakter empati anak. Hal tersebut membuktikan bahwa implementasi buku pedoman permainan tradisional efektif untuk menumbuhkan karakter empati pada anak usia 912 tahun. Untuk memberikan gambaran yang lebih jelas diperlukan analisis $N$-gain score. Analisis $N$-gain score untuk memastikan efektivitas penerapan buku pedoman permainan tradisional tersebut. Analisis menggunakan $\mathrm{N}$-gain score bertujuan untuk mengetahui tingkat efektivitas penerapan buku pedoman yang menggunakan metode permainan anak terhadap karakter empati. Analisis terhadap skor pretest dan posttest untuk karakter empati anak dengan kepercayaan $95 \%$ menunjukkan hasil nilai $N$-Gain Score sebesar $92.013 \%$ yang setara dengan tingkat efektivitas "Tinggi”. 
Tabel 2. Kriteria Besar Pengaruh Perlakuan

\begin{tabular}{ccc}
\hline $\boldsymbol{r}($ effect size) & Kategori & Persentase $(\%)$ \\
\hline 0,10 & Efek kecil & 1 \\
0,30 & Efek menengah & 9 \\
0,50 & Efek besar & 25 \\
\hline
\end{tabular}

\section{Discussion}

Berdasarkan hasil penelitian buku pedoman permainan tradisional menggunakan permainan anak efektif dalam meningkatkan karakter empati. Penguasaan nilai-nilai moral yang efektif perlu melibatkan moral knowing, moral feeling, dan moral action (Dewi, 2019; Mubarok, 2021). Pengembangan buku pedoman ini menggunakan analisis semantik. Analisis semantik adalah analisis yang mengacu pada struktur bahasa yang berhubungan dengan makna ungkapan. Analisis semantik digunakan untuk mengelompokkan kata kunci berdasarkan maknanya (Rohmah, 2016; Witasari \& Wiyani, 2020). Kata kunci yang digunakan adalah indikator dari karakter empati. Oleh karena itu, permainan anak berdampak secara signifikan terhadap pengembangan karakter empati secara holistik yang mencakup pengembangan tiga dimensi tersebut. Buku pedoman permainan tradisional dikembangkan dengan sepuluh indikator pembelajaran yang efektif menunjukkan adanya keterkaitan dengan teori Brain Based Learning, kompetensi pembelajaran abad 21, Piaget, Vygotsky, dan karakter empati. Dalam buku pedoman permainan tradisional ini ditunjukkan dengan lima permainan tradisional dari berbagai daerah beserta lagu daerah yang digunakan. Langkah-langkah setiap permainan juga dimodifikasi sesuai dengan indikator pembelajaran yang efektif yaitu kaya variasi. Tidak hanya itu, tetapi juga soal-soal yang dirancang baik soal formatif, sumatif, dan refleksi juga disusun bervariasi. Indikator kaya stimulasi ditunjukkan dengan anak memanfaatkan kemampuan indera yang dimiliki seperti mendengarkan, berbicara, dan melihat. Indikator menyenangkan diungkapkan anak dengan berekspresi dan berbagai reaksi anak ketika melakukan rangkaian kegiatan pengembangan permainan tradisional. Anak-anak bermain dengan alat atau media permainan yang disediakan termasuk dalam indikator operasional konkret. Setelah melakukan serangkaian kegiatan permainan tradisional yang sudah dirancang, lalu anak dituntut untuk berpikir kritis dengan mengerjakan soal evaluasi formatif, soal sumatif, dan menuliskan refleksi. Dalam mengerjakan soal refleksi dari setiap permainan, anak didorong untuk mengembangkan kreativitasnya (Hardiyanti et al., 2018; Lisa et al., 2020). Dari setiap rangkaian kegiatan, juga dapat diamati secara langsung bagaimana anak mengomunikasikan hal yang ingin disampaikan atau dirasakan dengan temannya atau fasilitator. Anak-anak saling berkolaborasi antar temannya untuk membentuk sebuah kelompok dalam permainan tradisional yang dikembangkan ini. Lima permainan tradisional dan lagu daerah yang dipilih berasal dari berbagai daerah yang ada di Indonesia yang menunjukkan indikator multikultur. Selain itu, dalam pengembangan permainan tradisional ini tentu saja terkandung nilai-nilai empati di dalamnya.

Temuan ini diperkuat dengan temuan sebelumnya yang menyatakan permainan tradisional dapat meningkatkan kemampuan gerak dasar siswa sekolah dasar kelas bawah (Kusumawati, 2017). Permainan congklak dapat meningkatkan keterampilan sosial pada mata pelajaran IPS (Handayani, 2017). Model pembelajaran dengan permainan tradisional engklek efektif sebagai sarana untuk menstimulasi aspek perkembangan anak berbantuan poster pada anak diteliti (Munawaroh, 2018). Bahan ajar tematik-integratif efektif dapat meningkatkan karakter tanggung jawab dan disiplin peserta didik (Baka et al., 2018; Hanida et al., 2019). Media komik efektif digunakan sebagai model pembelajaran karakter bagi siswa kelas V (Astiarini, 2016). Aktualisasi pendidikan karakter berbasis kultur sekolah dalam pembelajaran IPS dapat meningkatkan karakter siswa (Rosyad \& Zuchdi, 2018). Penelitian-penelitian terdahulu menerapkan permainan tradisional dan meningkatkan karakter dengan satu 
pendekatan saja. Sedangkan penelitian ini dapat diringkas dalam tiga unsur, yaitu multidimensi, konsentris, dan gradualitas. Model konsentris mencakup tiga wilayah yaitu wilayah pengaya, pendukung, dan inti. Wilayah pengaya meliputi pengembangan permainan tradisional dengan sepuluh indikator pembelajaran yang efektif yaitu kaya variasi, kaya stimulasi, menyenangkan, operasional konkret, berpikir kritis, kreativitas, komunikasi, kolaborasi, multikultur, dan empati. Wilayah pendukung meliputi permainan tradisional dari berbagai daerah yang berbeda, yaitu Nglarak Blarak dari Daerah Istimewa Yogyakarta, Grapyak dari Jawa Tengah, Rerebonan dari Jawa Barat, Landar-Lundur dari Jakarta Utara, dan Lompat Bambu dari Flores. Sedangkan, wilayah inti meliputi pendidikan karakter empati dengan sepuluh indikator, yaitu kepekaan sosial, peduli, memahami bahasa tubuh, memahami ekspresi, memahami kesedihan, memahami situasi, sadar kesalahan, menentang ketidakadilan, memahami pendapat lain, mengungkapkan secara lisan.

\section{CONCLUSION}

Buku pedoman permainan tradisional untuk menumbuhkan karakter empati anak usia 9-12 tahun dikembangkan sesuai langkah-langkah dalam ADDIE, yaitu Analyze, Design, Develop, Implement, dan Evaluate. Kualitas dari buku pedoman tradisional untuk pengembangan karakter empati anak usia 9-12 tahun adalah "sangat baik. Penerapan buku pedoman permainan tradisional berpengaruh terhadap karakter empati anak usia 9-12 tahun.

\section{REFERENCES}

Andrian, Y., \& Rusman, R. (2019). Implementasi pembelajaran abad 21 dalam kurikulum 2013. Jurnal Penelitian Ilmu Pendidikan, 12(1), 14-23. https://doi.org/10.21831/jpipfip.v12i1.20116.

Astiarini, W. (2016). Pengembangan model penanaman pembelajaran pendidikan karakter berbasis cerita melalui komik bagi siswa sekolah dasar kelas V. Jurnal Pendidikan Dasar UNJ, 7(1), 176-185. https://doi.org/10.21009/JPD.071.15.

Baka, A., Laksana, D. N. ., \& Dhiu, K. . (2018). Konten dan konteks budaya lokal Ngada sebagai bahan ajar tematik di Sekolah Dasar. Journal of Education Technology, 2(2), 46-55. https://doi.org/10.23887/jet.v2i2.16181.

Christopher, A. E., Waluyanto, H. D., \& Wahyudi, A. T. (2019). Perancangan Board Game Pembelajaran Toleransi Terhadap Perbedaan Pada Pelajaran Ppkn. Jurnal DKV Adiwarna, 2(15), 1-9. http://publication.petra.ac.id/index.php/dkv/article/view/9733.

Dewi, N. P. D. S. (2019). Pengaruh Metode Bercerita Berbasis Kearifan Lokal Terhadap Kemampuan Empati Anak Kelompok B1 TK Tunas Daud Kecamatan Denpasar Barat Tahun Ajaran 2018/2019. Jurnal Pendidikan Anak Usia Dini Undiksha, 7(1), 78-87. https://doi.org/10.23887/paud.v7i1.18761.

Estiani, W., Widiyatmoko, A., \& Sarwi. (2015). Pengembangan Media Permainan Kartu Uno Untuk Meningkatkan Pemahaman Konsep Dan Karakter Siswa Kelas VIITema Optik. Unnes Science Education Journal, 4(1), 711-719. https://doi.org/10.15294/usej.v4i1.4974.

Greipl, S., Klein, E., \& Lindstedt, A. (2021). When the brain comes into play: Neurofunctional correlates of emotions and reward in game-based learning. Computers in Human Behavior, 125. https://doi.org/10.1016/j.chb.2021.106946.

Groth, M., Barthe, K. G., Riemer, M., Ernst, M., Herrmann, J., Fiehler, J., \& Buhk, J. H. (2018). Critical Analysis of an e-Learning and Interactive Teaching Module with Respect to the Interpretation of Emergency Computed Tomography of the Brain. RoFo Fortschritte Auf Dem Gebiet Der Rontgenstrahlen Und Der Bildgebenden Verfahren, 190(4), 334-340. https://doi.org/10.1055/s-0043-124191. 
Handayani, P. (2017). Upaya peningkatan keterampilan sosial siswa melalui permainan tradisional congklak pada mata pelajaran IPS. Premiere Educandum: Jurnal Pendidikan Dasar Dan Pembelajaran, 7(1), 39-46. https://doi.org/10.25273/pe.v7i01.1245.

Hanida, Neviyarni, \& Fahrudin, F. (2019). Peningkatan Hasil Belajar Siswa Menggunakan Bahan Ajar Tematik Terpadu Berbasis Model Discovery Learning Di Kelas IV Sekolah Dasar. Jurna Basicedu, 3(2), 716 - 724. https://doi.org/10.31004/basicedu.v3i2.60.

Hardiyanti, Y., Husain, M. S., \& Nurabdiansyah, N. (2018). Perancangan Media Pengenalan Warna Untuk Anak Usia Dini. JURNAL IMAJINASI, 2(2), 43. https://doi.org/10.26858/i.v2i2.9553.

Haryanti, Y. D., \& Saputra, D. S. (2019). Instrumen Penilaian Berpikir Kreatif Pada Pendidikan Abad 21. Jurnal Cakrawala Pendas, 5(2). https://doi.org/10.31949/jcp.v5i2.1350.

Hidayah, N. (2015). Penanaman Nilai-nilai Karakter Dalam Pembelajaran Bahasa Indonesia di Sekolah Dasar. Jurnal Pendidikan Dan Pembelajaran Dasar, 2(2). https://doi.org/10.24042/terampil.v2i2.1291.

Juanda, J. (2019). Pendidikan Karakter Anak Usia Dini melalui Sastra Klasik Fabel Versi Daring. Jurnal Obsesi: Jurnal Pendidikan Anak Usia Dini, 3(1), 39. https://doi.org/10.31004/obsesi.v3i1.126.

Komara, E. (2018). Penguatan Pendidikan Karakter dan Pembelajaran Abad 21. SIPATAHOENAN: South-East Asian Journal for Youth, Sports \& Health Education, 4(1), 17-26. https://doi.org/10.2121/sip.v4i1.991.

Kurniati. (2016). Permainan tradisional dan perannya keterampilan sosial anak. Prenamedia Group.

Kusumawati, O. (2017). Pengaruh permainan tradisional terhadap peningkatan kemampuan gerak dasar siswa sekolah dasar kelas bawah. TERAMPIL: Jurnal Pendidikan Dan Pembelajaran Dasar, 4(2), 124-142. https://doi.org/10.24042/terampil.v4i2.2221.

Laksana, P, K., \& Niftalia, I. (2016). Pengembangan bahan ajar tematik SD kelas IV berbasis kearifan lokal masyarakat Ngada. Jurnal Ilmiah Pendidikan Citra Bakti, 3(1), 1-10. www.ejournal.citrabakti.ac.id/index.php/jipcb/article/view/74/0.

Lisa, M., Mustika, A., \& Lathifah, N. S. (2020). Alat Permainan Edukasi (APE) Meningkatkan Perkembangan Motorik Halus pada Anak Usia 4-6 Tahun. Jurnal Kesehatan, 11(1), 125. https://doi.org/10.26630/jk.v11i1.1584.

Mashar, R. (2015). Empati Sebagai Dasar Pembentukan KarakterAnak Usia Dini. In Jurnal Pendidikan Anak (Vol. 2, Issue 2). https://doi.org/10.21831/jpa.v2i2.3040.

Mubarok, A. A. S. A. Al. (2021). Alat Permainan Edukatif dalam Menanamkan Nilai Agama dan Moral Anak Usia Dini. Jurnal Inovasi Pendidikan Guru Raudhatul Atfha, 9(1). https://doi.org/10.21043/thufula.v9i1.10103.

Munawaroh, H. (2018). Pengembangan Model Pembelajaran dengan Permainan Tradisional Engklek Sebagai Sarana Stimulasi Perkembangan Anak Usia Dini. Jurnal Obsesi, 1(2), 86 - 96. https://doi.org/10.31004/obsesi.v1i2.19.

Nugrahani, F. (2017). The Development Of Film Based Literary Materials Which Suport Character Education. Jurnal Cakrawala Pendas, XXXVI(3), 472-486. https://doi.org/10.21831/cp.v36i3.14219.

Nurdin, N., Jahada, J., \& Anhusadar, L. (2021). Membentuk Karakter melalui Kegiatan Ekstrakurikuler Pramuka pada Anak Usia 6-8 Tahun. Jurnal Obsesi: Jurnal Pendidikan Anak Usia Dini, 6(2), 952-959. https://doi.org/10.31004/obsesi.v6i2.1603.

Nurohmah, A. N., \& Dewi, D. A. (2021). Penanaman Nilai Moral dan Karakter di Era Pandemi melalui Pendidikan dengan Mengimplementasikan Nilai-Nilai Pancasila. Journal of Education, Psychology and Counseling, 3(1), 119-128. https://ummaspul.ejournal.id/Edupsycouns/article/view/1305. 
Pitaloka, D. L., Dimyati, D., \& Edi, P. (2021). Peran Guru dalam Menanamkan Nilai Toleransi pada Anak Usia Dini di Indonesia. Jurnal Obsesi : Jurnal Pendidikan Anak Usia Dini, 5(2), 1696-1705. https://doi.org/10.31004/obsesi.v5i2.972.

Prasanti, D., \& Fitrianti, D. R. (2018). Pembentukan Karakter Anak Usia Dini: Keluarga, Sekolah, Dan Komunitas. Jurnal Obsesi: Jurnal Pendidikan Anak Usia Dini, 2(1), 1319. https://doi.org/10.31004/obsesi.v2i1.2.

Priska, V. H. (2020). Pentingnya Menanamkan Karakter Sejak Dini. EduPsyCouns: Journal of Education, Psychology, 2(1), 193-201. https://ummaspul.ejournal.id/Edupsycouns/article/view/433.

Priyanasari, F., \& Susanti, M. M. I. (2021). Pengaruh Akreditasi Sekolah Terhadap Implementasi PPK Berbasis Masyarakat Di SD Se-Kecamatan Ngaglik Kabupaten Sleman. In Elementary Journal (Vol. 3, Issue 2, pp. 78-89). https://repository.usd.ac.id/39665/1/7077_06\%2B2020.1.B\%2BJurnal\%2BTdk\%2BT erakreditasi\%2BEJ\%2BPPKBMN.pdf.

Putry, R. (2019). Nilai Pendidikan Karakter Anak Di Sekolah Perspektif Kemendiknas. Gender Equality: International Journal of Child and Gender Studies, 4(1), 39. https://doi.org/10.22373/equality.v4i1.4480.

Rakimahwati, Y. (2012). Upaya Meningkatkan Perkembangan Moral Anak Usia Dini Melalui Mendongeng Di Tk Dharmawanita Improving the Moral Development of Early Age Children. Ilmiah Visi P2TK PAUD NI, 7(1), 18-41. http://webcache.googleusercontent.com/search?q=cache:STZdc_RLneMJ:journal.unj. ac.id/unj/index.php/jiv/article/download/2675/2025+\&cd=3\&hl=id\&ct=clnk\&gl=id.

Ramadhani, P. R., \& Fauziah, P. Y. (2020). Hubungan Sebaya dan Permainan Tradisional pada Keterampilan Sosial dan Emosional Anak Usia Dini. Jurnal Obsesi : Jurnal Pendidikan Anak Usia Dini, 4(2), 1011. https://doi.org/10.31004/obsesi.v4i2.502.

Redhana, I. W. (2019). Mengembangkan Keterampilan Abad Ke-21 Dalam Pembelajaran Kimia. Jurnal Inovasi Pendidikan Kimia, 13(2), 2239-2253. https://journal.unnes.ac.id/nju/index.php/JIPK/article/view/17824.

Rohmah, N. (2016). Bermain Dan Pemanfaatannya Dalam Perkembangan Anak Usia Dini. Jurnal Tarbawi, 13(2), 27-35.

Rosyad, A. M., \& Zuchdi, D. (2018). Aktualisasi pendidikan karakter berbasis kultur sekolah dalam pembelajaran IPS di SMP. Armoni Sosial: Jurnal Pendidikan IPS, 5(1), 79-92. https://doi.org/10.21831/hsjpi.v5i1.14925.

Sugiarti, L., Purwanto, A., \& Sumantri, M. S. (2021). Literature Study of the Application of Brain Based Learning (BBL) Learning Models to Environmental Science Literacy. International Journal of Multicultural and Multireligious Understanding, 8(2), 374 384. https://doi.org/10.18415/ijmmu.v8i2.2349.

Sugiarto, A. P., Suyati, T., \& Yulianti, P. D. (2019). Faktor Kedisiplinan Belajar Pada Siswa Kelas X Smk Larenda Brebes. Mimbar Ilmu, 24(2), 232. https://doi.org/10.23887/mi.v24i2.21279.

Wisnu Budi Wijaya, I. K. (2019). Menanamkan Konsep Catur Paramita Pada Anak Usia Dini Di Lingkungan Keluarga Dan Sekolah. Pratama Widya : Jurnal Pendidikan Anak Usia Dini, 3(2), 41-46. https://doi.org/10.25078/pw.v3i2.737.

Witasari, O., \& Wiyani, N. A. (2020). Permainan Tradisional untuk Membentuk Karakter Anak Usia Dini. JECED : Journal of Early Childhood Education and Development, 2(1), 5263. https://doi.org/10.15642/jeced.v2i1.567.

Yustitia, V., \& Juniarso, T. (2018). Keefektifan Model Pembelajaran Brain Based Learning Terhadap High Order Thinking Skills (HOTS) Mahasiswa PGSD UNIPA Surabaya. MUST: Journal of Mathematics Education, Science and Technology, 3(2), 240 - 248. https://doi.org/10.30651/must.v3i2.2284. 